\title{
Transmisi Pesan dan Pemrosesan Informasi Individu Menyoal Diskriminasi di Indonesia dari Perspektif Van Kaam
}

\author{
Magfirah Magfirah1, Rizky Saputra² \\ 1Universitas Diponegoro \\ 2Universitas Islam Negeri Sumatera Utara \\ 1magfirahvhirah@gmail.com, ${ }^{2}$ rizkysaputra01b@gmail.com
}

\begin{abstract}
The goal of this research is to discover the experience of individuals processing information and interpret the phenomenon of discrimination in Indonesia. This study uses the interpretive paradigm and the phenomenological tradition as a basis for theoretical thinking to understand the subjective world of communicators through in-depth interview instruments. With the use of Information Integration Theory in order to to explain the process of forming cognitive structures and individual attitudes when interacting with discriminatory information obtained through a number of information media. The data analysis technique used the phenomenological approach proposed by Van Kaam. It is discovered in the research that information on discrimination cases appears in the daily activities of individuals accessing and using information, thus encouraging information processing in the individual's cognitive system. However, only a number of cases have been noticed and followed by individuals, such as cases of discrimination against ethnic Madurese in Kalimantan, Ahmadiyah congregations, students from Papua in Malang and Surabaya, and the Natalius Pigai case. Discrimination messages are transmitted via Facebook, Twitter, media coverage, research journals, and word of mouth. The phenomenon of discrimination in Indonesia is understood by individuals into three different meanings.
\end{abstract}

Keywords: Discrimination, Phenomenology, Natalius Pigai, Information Processing, Message Transmission

\section{Pendahuluan}

Ambroncius Nababan di akun media sosialnya cenderung menyulutkan reaksi emosional dari komentarnya dikarenakan konten komentar tersebut dinilai bernuansa diskriminasi ras. Ini bukan hal pertama dan hanya terjadi di media sosial. Berbagai aktifitas, baik digital maupun non-digital, yang bernuansa diskriminasi ras telah terjadi di Indonesia berberapa waktu ini. (Jatmiko, 2019) Kasus ini menyebabkan timbulnya realita sosial dimana kaum minoritas mendapatkan kesenjangan serius terhadap kaum mayoritas.

Pada tanggal 24 Januari 2021, salah satu trending topic di Twitter adalah rasisme, yang telah dicuitkan sebanyak 17.600 kali oleh pengguna. Komentar para pengguna ini berkaitan dengan kasus yang melibatkan Ambroncius Nababan.Sebuah akun bernama @jayapuraupdate mengungkapkan kejengkelan dengan menuliskan peringatan bahwa kasus Ambroncius Nababan dapat menyulut tragedi berdarah seperti di Jayapura, Wamena, dan daerah lain di Papua beberapa waktu lalu. Dirinya meminta aparat kepolisian untuk menangkap pelaku rasis, sehingga dapat mencegah terjadinya kerusuhan sosial. Komentar lain diungkapkan oleh akun bernama @YanHarahap yang mengecam bahwa komentar Ambroncius Nababan merupakan sikap yang mencerminkan sebagai manusia tidak berakhlak, karena Ambroncius pernah meminta dukungan, doa, dan restu dari warga Papua untuk menjadi wakil mereka di Dewan Perwakilan Rakyat (DPR) Republik Indonesia. 
Kecaman terhadap Ambroncius Nababan tidak hanya berasal dari warga atau netizen biasa. Roy Suryo, seorang tokoh, aktivis dan, politisi, juga mengecam komentar Ambroncius. Roy menyatakan bahwa komentar Ambroncius Nababan terhadap Natalius Pigai merupakan bentuk sikap rasis dan tidak pantas bagi kelompok warga masyarakat di Indonesia (Fensi, 2019). Dengan semakin mewabahnya kasus intoleransi antar umat beragama di Indonesia, prinsip non-diskriminasi dan kebebasan untuk menganut agama perlu ditekankan kepada berbagai kalangan masyarakat (Ananda \& Ramlan, 2020). Selain prinsip non-diskriminasi oleh pemerintah, dibutuhkan juga kesadaran masyarakat secara sejalan untuk mempertahankan persatuan di Indonesia.

Beberapa komentar di atas merupakan penilaian individu mengenai kasus rasisme yang melibatkan Ambroncius Nababan. Kasus ini berawal ketika dirinya membuat komentar dalam akun Facebook yang menampilkan foto Natalius Pigai, seorang aktivis pejuang Hak Asasi Manusia (HAM) yang berasal dari Papua, dengan menggunakan istilah gorila dan kadal gurun. Beberapa waktu setelah komentar tersebut beredar, muncul berbagai reaksi emosional dari masyarakat yang mengakses informasi atau komentar Ambroncius.Ungkapan emosional individu ini merupakan bentuk respon afektif yang berasal dari aktivitas individu membaca atau menyaksikan informasi yang berisi komentar Ambroncius Nababan. Respon afektif mendeskripsikan perasaan dan emosi individu dari sebuah stimulus. (Tinarbuko, 2019) Ekspresi emosional beberapa individu tersebut muncul, karena adanya gangguan kognisi setelah individu membaca komentar Ambroncius Nababan yang mengarah pada sikap diskriminasi. Diskriminasi dapat merusak kerjasama antarmanusia atau komunikasi diantara mereka. (Jatmiko, 2019; Lailawati, 2020) Oleh karena itu, diskriminasi dapat menghambat terbentuknya komunikasi antaretnis atau antarras yang mindful pada masyarakat Indonesia yang heterogen.

Berdasarkan data survei yang dilakukan oleh Yayasan Denny JA, pasca reformasi terdapat lebih dari 2.398 kasus kekerasan dan diskriminasi.Kekerasan dan diskriminasi dengan latar belakang agama memiliki jumlah kasus terbanyak, yaitu mencapai 65 persen.Sementara kasus etnis mencapai 20 persen, jender mencapai 15 persen, dan kasus orientasi seksual mencapai 5 persen. Selain itu, dari sejumlah kasus diskriminasi yang pernah terjadi di Indonesia, terdapat lima (5) aksi diskriminasi dan kekerasan yang terburuk. Penilaian aksi diskriminasi terburuk diskalakan dari korban, materi, tempat dan waktu serta frekuensi berita yang ditayangkan. Kasus tersebut yaitu kasus Ambon (8000-9000 korban meninggal), Sampit (469 korban meninggal), kerusuhan Mei 1998 1.217 korban meninggal), Ahmadiyah di Mataram (9 korban meninggal), dan kasus Lampung Selatan (14 korban meninggal). (Fadli, 2018)

Komentar Ambroncius Nababan terhadap Natalius Pigai dapat diindikasikan mengandung perspektif parokial. Parokialisme cenderung dikenal sebagai perilaku etnosentrisme yang dikaitkan oleh orang dari bangsa tertentu. Apabila terjadi parokialisme, sekelompok orang akan menguatkan ikatan sosial mereka untuk menolak interaksi antar individu atau kelompok yang berpandangan berbeda. (Wuri, 2017) 
Ketidakmampuan individu menerima perbedaan atau keberagaman sebagai sebuah keunikan, merupakan tantangan yang mendasar dalam relasi masyarakat multikultural.

Penelitian ini berfokus untuk mendeskripsikan pengalaman individu dalam memproses informasi dan memaknai fenomena kasusdiskriminasi di Indonesia, seperti yang dijabarkan dari sejumlah paragraf sebelumnya.

Prathama (2019) dalam penelitiannya menemukan pengalaman individual yang memproses dan memaknai SARA sebagai salah satu realita sosial di Indonesia yang terjadi di berberapa wilayah di Indonesia seperti Jakarta, Bekasi, hingga Semarang (Prathama, 2019).

Penelitian lainnya dilakukan oleh Shella Anggarini (2020) mengenai "Fenomena Dalam Berita COVID-19" mengungkap pengalaman individu memaknai fenomena COVID19 melalui berbagai informasi atau berita yang telah diakses individu. Semarang dipilih sebagai wilayah penelitian, karena menjadi salah satu zona merah penyebaran virus COVID-19 (Anggarini, 2020).

Penelitian-penelitian sebelumnya menggunakan konsep pemrosesan informasi dan pendekatan konseptual yang sama dengan penelitian ini, yaitu fenomenologi. Namun demikian, dalam penelitian ini kasus yang dikaji adalah informasi mengenai kasus diskriminasi, termasuk komentar dari Ambroncius Nababan yang diunggah di Facebook. Information-Integration Theory menjadi teori yang menompa penelitian untuk menjelaskan bagaimana pembentukan sikap individu setelah mengkonsumsi informasi.

Latar belakang yang telah dibahas melahirkan sebuah ide penelitian untuk mengilustrasikan pengalaman individu dalam memproses informasi yang berkaitan dengan diskriminasi kepada masyarakat Indonesia.

\section{Metode Penelitian}

Penelitian yang dirancang menggunakan pendekatan kualitatif. Pendekatan kualitatif akan mengkaji secara mendalam bagaimana dari komentar media sosial dari akun Ambroncius Nababan mengkonstruksi realita SARA di Indonesia. (Assyaukanie, 2018) Objek utama dari penelitian ini berupa peneliti yang akan terjun kedalam media sosial dimana kobaran api diskriminasi masih belum padam. Sehingga penelitian ini akan memiliki perspektif tradisi Fenomenologi. Fenomenologi merupakan cara manusia untuk berusaha memahami dunia melalui pengalamannya secara langsung dan menjelaskan bagaimana individu menginterpretasikan makna dari sebuah fenomena sosial. Interpretasi, dalam pendekatan ini, secara harafiah membentuk apa yang nyata bagi orang tersebut. (Littlejohn \& Foss, 2008)

Paradigma Interpretif. Salah satu paradigma dalam penelitian kualitatif adalah paradigma interpretif. Paradigma interpretif menganggap bahwa tindakan manusia dipandu oleh seperangkat keyakinan dasar dan perasaan mengenai dunia dan memandang bagaimana dunia harus dipahami dan dipelajari. (Rochim, Bajari, Damayani, \& Bakti, 2020) Paradigma interpretif menungkap bagaimana pengalaman individu 
bersifat subyektif dan bertujuan untuk memahami sebuah perilaku dalam fenomena sosial. (Hermawan, Salim, Rohman, \& Rahayu, 2019)

Paradigma Interpretif juga diproposisikan untuk memahami makna universal yang dipandu oleh prinsip yang abstrak. Serta melibatkan peneliti terhadap fenomena sosial. Oleh karena itu, peneliti harus terjun kedalam sebuah fenomena untuk berinteraksi secara natural kepada target penelitian. (Livari, 2018)

Pada penelitian ini, paradigma interpretif digunakan sebagai pijakan berpikir teoritik untuk memahami dunia pengalaman individu yang mengkonsumsi informasi atau berita mengenai kasus diskriminasi yang pernah terjadi di Indonesia, yang bersifat subyektif.

Bukti-bukti dalam penelitian fenomenologi diperoleh melalui laporan orang pertama secara langsung tentang pengalaman hidupnya (Moustakas, 1994 : 84). Dalam konteks penelitian ini, pengalaman yang dimaksud adalah pengalaman dari 2 orang individu yang memiliki akun Facebook atau Twitter secara aktif serta mencermati adanya kasus diskriminasi di Indonesia, sehingga dimungkinkan memiliki pengalaman yang relevan dengan permasalahan penelitian ini.

Data primer yang berwujud pengalaman individu diperoleh melalui instrumen indepth interview (wawancara mendalam). Untuk analisis data penelitian, teknik Van Kaam yang terdiri dari 7 tahapan, yaitu pendaftaran, reduksi, kluster tematik, identifikasi akhir, deskripsi tekstural individu, deskripsi struktural individu hingga deskripsi gabungan yang dilakukan secara berurutan, akan digunakan dalam penelitian ini. (Forber-Pratt \& Espelage, 2018) Rangkaian proses analisis data ini akan memandu peneliti menemukan esensi pengalaman individu yang berinteraksi dengan informasi kasus diskriminasi yang pernah terjadi di Indonesia.

Tentunya, teknik Van Kaam bukan kali pertama dalam penelitian ini. Peneliti telah menemukan sejumlah penelitian yang menggunakan teknik analisis yang serupa untuk memperkuat penjelasan fenomenologi Van Kaam sebagai model analisis wawancara. Salah satu contohnya terdapat dalam penelitian yang dikonduksi Khalsa dengan penyedia layanan pengungsi sebagai objek penelitian. Hasil yang ditarik dari penelitian yang menggunakan wawancara mendalam menggunakan teknik analisis Van Kaam menunjukkan komodifikasi sumber daya dari pengungsi yang tinggal di pesisir Kolorado Utara untuk bertahan hidup (Khalsa, Welle, Royse, \& Kopystynsky, 2020). Tidak hanya itu, polemik akulturasi dalam wilayah pengungsian di Kolorado menjadi sebuah urgensi yang tidak terhindari dari sejumlah aspek baik dari pengetahuan, komunikasi hingga bahasa.

Penelitian dengan teknik analisis Van Kaam sebelumnya beralih kepada dunia kesehatan dimana Kim meneliti sebuah klinik perawat dimana terjadi potensi bullying di lingkungan kerja. Hasil analisa wawancara menunjukkan bahwa hukum anti-bullying tidak serupa dengan praktik lapangan, dimana masih terdapat fenomena bullying dalam lingkungan kerja, khususnya dalam institusi kesehatan (Kim \& Sim, 2021). Contoh 
penelitian yang menggunakan teknik analisis yang serupa terkonduksi kembali di industri kesehatan. Zuccarini menginvestigasi para perawat yang baru saja meraih gelar mereka dalam melaksanakan tugas mereka di dunia kerja. Menggunakan metode wawancara, serta 14 perawat lulusan Universitas Milan sebagai objek penelitian, ditemukan sejumlah cara perawat dalam menjalankan pekerjaan mereka, diantaranya relasi teori dengan praktek untuk membantu pemikiran klinis yang lebih komprehensif dan jam terbang perawat selama bekerja dalam institusi kesehatan (Zuccarini, Ledonne, \& Bonetti, 2017).

Handoko menggunakan tujuh tahapan analisa Van Kaam untuk wawancara sebagai instrumen penelitian organisasi mahasiswa yang menjadi sumber pengalaman untuk mahasiswa saat mereka lulus. Dari hasil penelitian yang melibatkan 40 responden, 15 diantaranya merupakan mahasiswa yang aktif dalam organisasi mahasiswa, menunjukkan peningkatan kemampuan komunikasi, kinerja dalam tim dan adaptabilitas mahasiswa dalam memasuki lingkungan baru (Handoko, 2021). Organisasi mahasiswa terbukti dapat mempersiapkan mahasiswa untuk menjadi pribadi yang mandiri di dunia kerja.

Bovin pada tahun 2019 meneliti Direktur Band SMA Putri untuk mengklarifikasi kontroversi diantara peran perempuan dalam organisasi band musik di SMA. Penelitian yang menggunakan modifikasi fenomenologi Van Kaam ini menunjukkan bahwa terdapat implikasi diskriminasi kepada perempuan sebagai anggota band dan menerima sejumlah respon negatif dalam kelasnya (Bovin, 2019). Penelitian Bovin mengklarifikasi negativitas peran perempuan dalam aktifitas organisasi dalam institusi pendidikan dan menekan urgensi pihak sekolah untuk berpartisipasi dalam mendukung peran perempuan dalam organisasi sekolah seperti band musik, serta peran direktur band dalam menyuarakan kesulitan mereka selama berada dalam band.

Miller juga menggunakan teknik analisis yang serupa untuk meneliti pengalaman terapi spiritual untuk menekan stigma penderita HIV di Amerika Serikat. Berdasarkan data penelitian melalui sepuluh responden menunjukkan teknik spiritualitas sebagai model penguatan rohani penderita HIV. Partisipan merasakan stigma HIV mendorong mereka lebih dekat kepada kepercayaan spiritual yang berhasil mempengaruhi penderita HIV untuk menerima medikasi yang dibutuhkan untuk melanjutkan kelangsungan hidup (Miller, 2020). Studi ini menjadi contoh pengalaman spiritual dapat dipraktikan kepada institusi kesehatan untuk memberikan pengobatan kepada pasien dengan penyakit kronis, dengan HIV sebagai penyakit khusus dalam penelitian ini.

Mafaza menyelidiki teknik pengasuhan orang tua tuna netra terhadap anak usia dini menggunakan fenomenologi modifikasi Van Kaam sebagai teknik analisis penelitian. Berdasarkan hasil wawancara, orang tua tuna netra yang berprofesi sebagai tukang pijat merasa dihalau keterbatasan fisik dan pengalaman mendidik anak, namun tidak menyulutkan semangat mereka dalam mendidik anak mereka untuk meraih masa depan yang lebih baik (Mafaza, Anggreiny, \& Alfara, 2018). Yunitasari juga menginterpretasikan budaya Omed-Omedan di Bandar Kaja, Denpasar, Bali sebagai model pemahaman adat 
istiadat daerah tersebut. Penelitian yang menggunakan teknik analisa Van Kaam dari hasil wawancara, observasi dan dokumentasi mendapat sebuah hasil dimana tradisi OmedOmedan menginterpretasikan solidaritas antar manusia sebagai makhluk sosial. Makna dari tradisi ini juga menunjukkan pengukuhan solidaritas dalam komunitas Bandar Kaja (Yunitasari, Kanto, \& Chawa, 2018)

Ekspansi teknik analisis yang serupa juga dilakukan oleh Indrasari dimana penelitian dilakukan kepada pewirausaha perempuan yang sukses dalam menjalani usaha selama lima tahun atau lebih sembari bertanggung jawab atas pekerjaan rumah tangga. Melalui 10 responden, teridentifikasi 8 dari 10 kriteria kesuksesan pewirausaha yang mencerminkan kegigihan perempuan di Surabaya dalam menjalani sejumlah tanggung jawab sekaligus (Indrasari, Purnomo, Yunus, Syamsudin, \& Kartini, 2018). Hasil penelitian dari Indrasari juga dapat menginspirasi kaum perempuan dari wilayah lain untuk menjadi pelaku usaha berikutnya untuk mendukung perekonomian Indonesia.

Penelitian yang dikonduksi menggunakan teknik analisis yang serupa berpindah kedalam bidang penerbangan. Borisuth menginvestigasi Bandara Suvarnabhumi di Thailand untuk meninjau kinerja sistem organisasi bandara dalam memecahkan permasalahan penumpang. Hasil penelitian yang dikonduksi menunjukkan lima tema yang muncul selama analisis berupa ekspektasi konsumen, struktur yang terancang, kepemimpinan, sumber daya manusia dan perlindungan konsumen. Perlindungan konsumen menjadi tema kebaruan dalam penelitian tersebut mengingat studi yang dilakukan dalam penelitian sebelumnya tidak menunjukkan korelasi tema perlindungan konsumen dengan keempat tema yang umum (Borisuth, 2019).

Penelitian yang telah dilakukan sebelumnya juga berada pada dunia olahraga dimana pelatihan Taekwondo menjadi salah satu sarana peningkatan kesehatan jasmani dan rohani. Bing dalam penelitiannya menggunakan analisis Van Kaam mewawancarai 12 responden dengan rentang usia 20 sampai dengan 25 tahun. Penelitian ini menunjukkan enam tema dari fenomenologi Taekwondo sebagai pemulihan kesehatan rohani, berupa penghilangan emosi yang terpendam, menghilangkan rasa takut, melepaskan rasa etik, pelepasan perasaan melalui peniruan, pemurnian perasaan rasa kepuasan dari hasil kinerja tim dan melepaskan perasaan iri dari individu itu sendiri (Bing \& Kim, 2021). Sebagai seni bela diri di Korea, Taekwondo tidak hanya melatih kebugaran jasmani, namun juga memurnikan pikiran dan rohani pesertanya.Sejumlah contoh penelitian diatas menunjukkan ekspansi dari teknik analisis Van Kaam selain dari bidang kesehatan dan psikologi. Penelitian ini menjadi sebuah kebaruan mengingat teknik analisis Van Kaam diterapkan melalui media sosial dalam dunia digital untuk memaknai pengalaman diskriminasi dalam media sosial yang marak terjadi di dunia digital Indonesia.

\section{Hasil Penelitian Dan Pembahasan}

\section{Pengalaman Individu Berinteraksi Dengan Informasi Diskriminasi}

Aktivitas informan sehari-hari, didominasi dengan aktivitas bekerja di sebuah perguruan tinggi swasta dan berbisnis digital (e-commerce), sehingga mendorong para 
informan untuk berinteraksi dengan beragam informasi yang berkaitan dengan aktivitas utamanya tersebut seperti informasi akademik atau ilmiah, mengakses perkembangan berita dari portal berita online (detik.com, tempo.co.id, okezone.com, dan kompas.com), situs resmi instansi, serta sejumlah informasi yang berkaitan dengan bisnis e-commerce (startup rangking).Beragam informasi yang diakses para informan, sebagian besar diakses melalui internet dengan menggunakan handphone serta laptop (komputer).

Informasi lainnya yang bermanfaat sebagai tambahan pengetahuan seperti kesehatan, sosialisasi dengan teman dan kerabat, keuangan, kurs valuta asing, dan lainlain, juga diakses oleh informan melalui media sosial Facebook, Twitter, Instagram, dan aplikasi What's apps. Menurut Yusriyah (2020), keunikan media sosial adalah membentuk masyarakat untuk saling berjejaring, sehingga pertukaran informasi dapat berkelanjutan. (Yusriyah, Fatoni, \& Mansyur, 2020) Informan tidak hanya menggunakan media sosial untuk berinteraksi dengan sesama pengguna, namun juga mengakses berbagai informasi terbaru lainnya, yang tidak dapat diperoleh melalui media lain. Kepahaman pengguna media sosial untuk memproses informasi lebih dahulu menjadi sebuah urgensi dalam menerima informasi di dunia digital.

Kemunculan informasi yang berkonten tentang kasus diskriminasi, pada awalnya diperoleh informan melalui sejumlah media sosial seperti Facebook, Twitter dan Youtube, ketika mereka sedang melakukan pencarian informasi yang berkaitan dengan aktivitas utama, sehingga mendorong perhatian informan untuk mencermati kasus tersebut. Jenis kasus diskriminasi yang dicermati oleh informan terdiri dari kasus diskriminasi etnis Madura di Kalimantan, jemaat Ahmadiyah, pengikut Syiah, umat Kristen di Aceh, umat Islam di Papua, mahasiswa Papua di Malang dan Surabaya, serta kasus Natalius Pigai.

\section{Pengalaman Individu Memproses Informasi Diskriminasi}

Pada awalnya, kemunculan informasi atau berita yang berkaitan dengan kasus diskriminasi tidak menjadi informasi prioritas yang dicari oleh para informan.Namun demikian, sejumlah kasus diskriminasi yang menjadi perhatian publik dan menjadi viral (virus digital) di Twitter atau Facebook, mendorong informan untuk mencermati serta mengikuti perkembangannya.

Fenomena itu memperlihatkan bahwa dalam tahap ini, sejumlah informasi kasus diskriminasi mulai menerpa para informan. Ikasari (2017) menunjukkan stereotipisme dari para informan menjadi akar dari permasalahan diskriminasi di Indonesia. (Ikasari, 2017) Namun demikian, tidak setiap informasi kasus diskriminasi yang menerpa para informan, mendapat perhatian dari mereka untuk mengikuti perkembangannya. Informan melakukan selective attention, yaitu melibatkan diri dengan stimulus-stimulus yang berbeda, (Gelso, 2015) ketika berinteraksi dengan informasi kasus diskriminasi. Dalam konteks penelitian ini, stimulus atau informasi kasus diskriminasi yang dikonsumsi oleh dua orang informan tidak sama. Informan 1 mengaku hanya mengikuti perkembangan kasus diskriminasi jemaat Ahmadiyah, pengikut Syiah, umat Kristen di Aceh, dan kasus Natalius Pigai. Sementara informan 2 mengikuti perkembangan kasus 
diskriminasi etnis Madura di Kalimantan, jemaat Ahmadiyah, umat Islam di Papua, mahasiswa Papua di Malang dan Surabaya, serta kasus Natalius Pigai. Kasus Natalius Pigai menjadi kasus yang diikuti perkembangannya oleh kedua orang informan, karena relatif baru dan viral di publik.

Ketika informan mengikuti perkembangan informasi kasus diskriminasi, terjadi aktivitas pemrosesan informasi dalam sistem kognitif individu. Pemrosesan informasi adalah sebuah proses ketika individu diarahkan menuju informasi-mencari, memahami, serta menempatkan informasi di dalam memori-dan mengundangnya untuk digunakan kembali. (Adi, 2019) Para ilmuwan psikologi kognitif menyatakan bahwa beragam informasi akan mengekspos individu secara besar-besaran.Namun demikian, hanya sebagian kecil yang dapat mencapai pikiran sadar dan disimpan dalam memori jangka panjang melalui proses filter. (Fox \& Holt, 2018) Oleh karena itu, dari seluruh kasus diskriminasi yang dicermati dan diikuti perkembangannya, hanya sebagian yang dapat diceritakan oleh kedua orang informan dengan relatif utuh.

Dalam perspektif Information-Integration Theory dijelaskan bahwa komunikator akan menghimpun dan mengorganisasikan informasi tentang orang, obyek, situasi, dan ide untuk membentuk sikap-kecenderungan bertindak dalam cara positif atau negatif terhadap obyek. (Littlejohn \& Foss, 2008) Informasi diskriminasi yang diikuti perkembangannya oleh para informan yaitu kasus diskriminasi etnis Madura, Jemaat Ahmadiyah, Mahasiswa Papua (Malang dan Surabaya), serta kasus Natalius Pigai.Informan cenderung memberikan valensi positif dan bobot bagi informasiinformasi diskriminasi tersebut.

Kasus diskriminasi etnis Madura terjadi ketika warga keturunan etnis Madura ingin kembali ke daerah bekas konflik di Kalimantan Tengah.Informasi ini diikuti oleh informan melalui berbagai sumber seperti Facebook, Twitter, pemberitaan media, jurnal penelitian, dan cerita pengalaman sejumlah individu Madura yang dikenalnya.

Sementara informasi kasus diskriminasi jemaat Ahmadiyah diikuti informan melalui berita media dan sejumlah jurnal penelitian.Informan menyoroti bahwa kasus jemaat Ahmadiyah yang membawa korban luka dan meninggal, sering terjadi di wilayah Pulau Jawa seperti Jakarta, Jawa Barat, dan Banten.

Berita mengenai kasus diskriminasi terhadap mahasiwa Papua di Malang dan Surabaya, diikuti oleh informan melalui Facebook, Twitter, dan pemberitaan televisi. Salah satu contohnya terdapat dalam akun Instagram @Infia_Fact yang mempublikasi sebuah post terkait Patung Kwan Sing Tee di Tuban yang menuai banyak kontroversi dari warga digital di Indonesia (Marta, 2018). Post yang mendapat sekitar 4000 komentar tersebut bernuansa positif dan negatif tanpa ada niatan dari penggunggah untuk menyulut sebuah konflik, melainkan menjabarkan sebuah fakta. Contoh lainnya tercermin dalam sebuah post dari media sosial Instagram melalui akun Felix Siauw. Dalam akun tersebut, Hannan menemukan komodifikasi diskriminasi menggunakan narasi 
antikemapanan, antiotoritan dan narasi bujukan untuk kembali ke nilai-nilai agama muslim (Hannan, 2021).

Polemik lainnya yang merusak citra Indonesia menggunakan diskriminasi juga terjadi di sejumlah post media sosial Facebook dan Twitter yang berhubungan dengan Pilkada Jakarta 2018. Lahir sejumlah post yang berusaha menyudutkan satu kelompok suku, ras atau agama dengan tujuan politik (Tinarbuko, 2019). Efek yang masif terasa oleh kelompok suku yang terdampak berlanjut hingga kampanye Pemilihan Presiden tahun 2019 dimana kelompok media sosial memanfaatkan diskriminasi sebagai strategi kampanye untuk memenangkan Pilpres 2019.

Kasus diskriminasi yang diterima oleh Natalius Pigai merupakan kasus diskriminasi terbaru yang dicermati dan diikuti oleh para informan dengan penuh emosional melalui Facebook, Twitter, dan pemberitaan televisi. Bahkan pada bulan Januari 2021, kasus ini menjadi salah satu topik yang hangat dibicarakan di media sosial Twitter.

Polemik informasi diskriminasi di media sosial yang dipaparkan diatas menunjukkan bahwa kasus diskriminasi ini dapat menyulut adanya kerusuhan di Provinsi Papua dan Papua Barat yang menyerang warga pendatang.

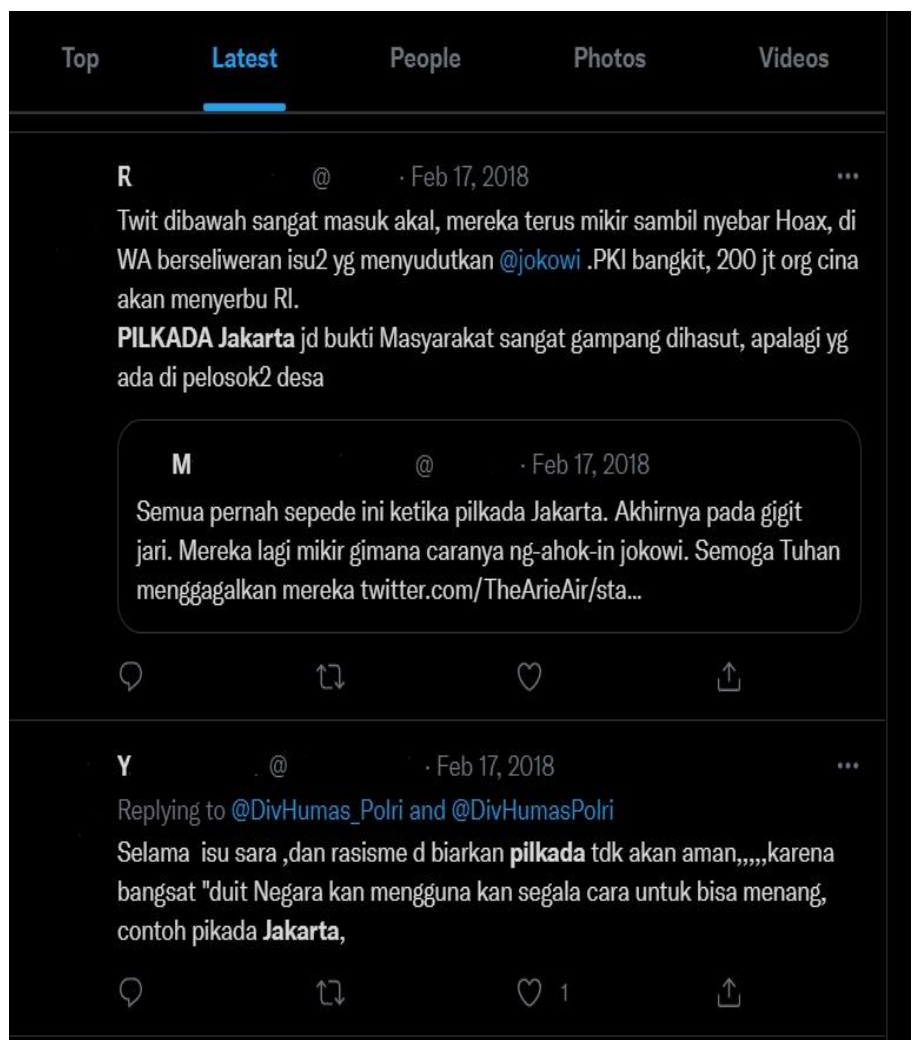

Gambar 1. Cuplikan Post Terkait Pilkada Jakarta pada Tahun 2018 (Sumber: Twitter)

Perilaku mengkonsumsi informasi kasus diskriminasi oleh para informan, mendorong terbentuknya struktur (pengetahuan) kognitif mengenai fenomena diskriminasi di dalam sistem kognitif individualnya. Koch (2018) menjelaskan struktur 
kognitif sebagai rangkaian sifat yang terkumpul dan digunakan individu untuk melakukan identifikasi serta diskriminasi terhadap suatu obyek atau peristiwa tertentu. (Koch, Poljac, Müller, \& Kiesel, 2018) Struktur kognitif individu terbentuk melalui rangkaian proses pemahaman individu dari informasi kasus diskriminasi yang telah terproses. Pemahaman merupakan cara individu mengorganisasikan dan menginterpretasikan informasi yang diperoleh individu. Mirawati (2017) menuturkan 4 faktor pemahaman individu yang berupa pengalaman kesuksesan, pengalaman individu lainnya, persuasi verbal dan kondisi fisiologis, untuk memperkuat keyakinan diri. (Mirawati, 2017)

Proses pemahaman individu, dalam konteks ini, terjadi ketika individu berinteraksi dengan informasi kasus diskriminasi yang diperhatikan dan diikutinya secara berkelanjutan, sehingga mendorong terjadinya perubahan skema kognitif dan sikap individu. Cristea (2020) menyatakan bahwa skema kognitif merupakan sebuah naskah yang terdapat di dalam pikiran individu mengenai alur dari suatu kejadian atau peristiwa tertentu (Cristea, Valencia, \& Curelaru, 2020). Oleh karena itu, ketika individu memberikan perhatian pada informasi kasus diskriminasi tertentu, informasi tersebut terproses, yang kemudian akan terjadi penambahan input di dalam sistem kognitif individu, yang terungkap melalui berbagai pandangan, komentar, gagasan, penilaian, ekspresi emosional, atau perilaku komunikasi tertentu mengenai obyek kasus diskriminasi.

Sementara sikap didefinisikan sebagai perasaan yang tercermin dalam kepribadian manusia,baik negatif atau positif,yang ditujukan secara langsung maupun berkelanjutan terhadap seseorang, obyek, atau masalah, (Sholiha \& Aulia, 2020) yang terwujud melalui ungkapan atau ekspresi emosional individu seperti kemarahan, kecewa, tenang, dan perilaku komunikasi lainnya ketika berinteraksi dengan informasi kasus diskriminasi.

Diskriminasi, dalam pandangan Solihah (2017), merupakan tindakan nyata dari adanya variasi atau beragam ancaman yang tidak seimbang terhadap orang lain. (Solihah \& Witianti, 2017) Namun demikian, dalam konteks kasus ini, diskriminasi dipahami ke dalam tiga pemaknaan oleh para informan. Pertama, diskriminasi merupakan sikap negatif yang diarahkan seseorang kepada orang lain untuk merendahkan martabatnya sebagai manusia. Termasuk di dalamnya terdapat pandangan bahwa diri atau kelompoknya memiliki tingkat yang lebih tinggi daripada kelompok dan individu lain. Kasus diskriminasi yang dialami oleh mahasiswa Papua di Malang dan Surabaya dengan menirukan suara binatang kera, memperlihatkan bahwa para pelaku menganggap para mahasiswa Papua ini sebagai binatang, yang dapat diartikan memiliki derajat lebih rendah daripada manusia. Sebagai akibat dari adanya kasus ini, terjadi kerusuhan di Papua dan Papua Barat yang melibatkan antara suku-suku asli Papua dengan para pendatang.

Kasus Natalius Pigai, juga hampir sama dengan kasus yang dialami oleh mahasiswa di Malang dan Surabaya. Secara emosional, informan menyatakan bahwa Natalius Pigai disebut bukan manusia, karena dianggapsebagai gorila dan kadal gurun oleh Ambroncius 
Nababan.Beberapa waktu kemudian, kasus ini memicu kemarahan publik.Sejumlah tokoh memberikan komentar yang menyalahkan Ambroncius, karena komentar Ambroncius dinilai tidak pantas diucapkan oleh tokoh publik.

Kedua, diskriminasi adalah tindakan yang merugikan seseorang, karena adanya perbedaan latar belakang atau identitas manusia secara individual dan kelompok.Kasus diskriminasi yang dialami oleh jemaat Ahmadiyah terjadi, karena tidak meyakini bahwa Nabi terakhir adalah Nabi Muhammad SAW.Penyerangan kelompok Ahmadiyah yang diberitakan secara nasional, seolah memicu kelompok lain untuk melegalkan penyerangan kelompok Ahmadiyah di sejumlah daerah. Informan menyesalkan terjadinya kasus ini, karena Negara dinilai tidak hadir untuk menyelesaikan masalah Ahmadiyah dengan tegas dan jelas.

Ketiga, diskriminasi merupakan sikap dan tindakan negatif yang berasal dari rasa benci seseorang terhadap orang lain, karena tidak memiliki kecakapan komunikasi antarbudaya yang mindful dalam kerangka kebangsaan yang multikultur. Kasus diskriminasi yang dialami oleh warga etnis Madura ini terjadi pada fase awal mereka kembali ke daerah bekas konflik di Kalimantan (Sampit dan Sambas). Mereka ditolak untuk kembali ke Kalimantan oleh warga asli (Dayak dan Melayu), karena adanya memori negatif mengenai perilaku sejumlah oknum warga etnis Madura yang bertindak kriminal dan memicu terjadinya konflik terbuka tahun 1999 serta 2001, sehingga memunculkan rasa benci yang bersifat kolektif diantara warga asli.

Jika disimpulkan secara singkat, diskriminasi dapat dipahami individu ke dalam tiga makna. Pertama, diskriminasi merupakan sikap negatif yang diarahkan seseorang kepada orang lain untuk merendahkan martabatnya sebagai manusia. Termasuk di dalamnya terdapat pandangan bahwa diri atau kelompoknya memiliki tingkat yang lebih tinggi daripada kelompok dan individu lain. Kedua,diskriminasi adalah tindakan yang merugikan seseorang, karena adanya perbedaan latar belakang atau identitas manusia secara individual dan kelompok.Ketiga, diskriminasi merupakan sikap dan tindakan negatif yang berasal dari rasa benci seseorang terhadap orang lain, karena tidak memiliki kecakapan komunikasi antarbudaya yang mindful dalam kerangka kebangsaan yang multikultur.

Fenomena yang menonjol dalam konteks diskriminasi dan ditemukan oleh informan penelitian ini, berwujud diskriminasi agama dan etnis atau ras,meskipun para pendiri bangsa telah menyerukan bahwa Indonesia merupakan Negara yang beragam adat-istiadat, sehingga masyarakat perlu mempelajari dan memahaminya secara menyeluruh. Secara tersirat, informan menyatakan bahwa persoalan mendasar dari masyarakat Indonesia ini belum terselesaikan, karena masyarakat belum mampu untuk menerima perbedaan secara ikhlas.

\section{Kesimpulan}

Informasi mengenai kasus diskriminasi yang diakses oleh individu, muncul dalam aktivitas individu mencari dan menggunakan informasi untuk aktivitas sehari-hari.Kasus 
diskriminasi yang dialami oleh Natalius Pigai dan memicu kemarahan publik, menjadi salah satu kasus diskriminasi yang diperhatikan dan diikuti perkembanganya. Selain itu, terdapat kasus diskriminasi lainnya yaitu kasus diskriminasi etnis Madura di Kalimantan, kasus jemaat Ahmadiyah, dan kasus mahasiswa Papua di Malang serta Surabaya.

Informasi kasus diskriminasi yang diikuti perkembangannya oleh individu ditransmisikan melalui sejumlah media seperti Facebook, Twitter, pemberitaan televisi (media), jurnal penelitian, dan cerita pengalaman korban (word of mouth).Ketika individu memperhatikan dan mengikuti perkembangan kasus diskriminasi, terjadi pemrosesan informasi, sehingga mendorong terbentuknya struktur kognitif di dalam sistem kognitifnya, yang berasal dari pemahaman mengenai fenomena diskriminasi.

Berdasarkan hasil penelitian ini, implikasi praktis diarahkan kepada masyarakat Indonesia agar dapat memahami perbedaan identitas sebagai sebuah anugerah (takdir) dari Tuhan yang tidak dapat dihapuskan, sehingga dapat memahami keberagaman dalam tataran empatik.

Penelitian ini, seperti penelitian lainnya, memiliki keterbatasan sendiri. Objek penelitian terbatas hanya kedalam satu akun dengan nama Ambrocius Nababan. Eksplorasi fenomena akun lainnya yang memiliki konteks serupa dengan Ambrocius Nababan menjadi saran kepada praktisi yang ingin mendalami diskriminasi di dunia digital, baik di Indonesia ataupun mancanegara, dalam waktu mendatang untuk memberikan konteks komparasi antar sejumlah akun dengan similaritas konteks.

\section{Daftar Pustaka}

Adi, W. (2019). ANALISIS TEKSTUAL GAYA BAHASA IKLAN HARBOLNAS VERSI SAKIT JIWA TOKO ONLINE BUKALAPAK.COM DI INTERNET. Communicology: Jurnal Ilmu Komunikasi. https://doi.org/10.21009/communicology.0602.01

Ananda, P. D., \& Ramlan, R. (2020). Prinsip Non-Diskriminasi dalam Penerapannya pada Peraturan Bank Indonesia tentang Gerbang Pembayaran Nasional. Uti Possidetis: Journal of ..., 1(1), 67-89. Retrieved from https://onlinejournal.unja.ac.id/Utipossidetis/article/view/8434

Anggarini, S. (2020). Fenomena Dalam Berita COVI-19. Jurnal Audience, 3(2), 224-249. https://doi.org/10.33633/ja.v3i2.3628

Assyaukanie, L. (2018). Akar-Akar Legal Intoleransi dan Diskriminasi di Indonesia. Maarif, 13(2), 27-42. https://doi.org/10.47651/mrf.v13i2.20

Bing, W. C., \& Kim, S. J. (2021). A phenomenological study of mental health enhancement in taekwondo training: Application of catharsis theory. International Journal of Environmental Research and Public Health, 18(8). https://doi.org/10.3390/ijerph18084082

Borisuth, A. (2019). The Infuence of Organizational Structure on Customer Issue Resolution: A Phenomenological Study on Suvarnabhumi Airport in Thailand. GSPA, 26(1), 69-87. Retrieved from https://so03.tci- 
thaijo.org/index.php/ppmjournal/article/view/199449

Bovin, A. J. (2019). Breaking the Silence: The Phenomenology of the Female High School Band Director. Update: Applications of Research in Music Education, 38(1), 34-45. https://doi.org/10.1177/8755123319841664

Cristea, M., Valencia, J. F., \& Curelaru, M. (2020). Quantitative and qualitative centrality of a social representation's core elements: The use of the basic cognitive schemes model. Journal of Social and Political Psychology, 8(1), 351-367. https://doi.org/10.5964/jspp.v8i1.771

Fadli, Y. (2018). Islam, Perempuan dan Politik: Argumentasi Keterlibatan Perempuan dalam Politik di Indonesia Pasca Reformasi. Journal of Government and Civil Society. https://doi.org/10.31000/jgcs.v1i1.267

Fensi, F. (2019). PARADOXIC LANGUAGE “CEBONG-KAMPRET” IN FACEBOOK AS A MIRROR OF THE POLITICAL LANGUAGE OF INDONESIA. Bricolage : Jurnal Magister Ilmu Komunikasi. https://doi.org/10.30813/bricolage.v5i02.1887

Forber-Pratt, A. J., \& Espelage, D. L. (2018). A Qualitative Investigation of Gang Presence and Sexual Harassment in a Middle School. Journal of Child and Family Studies. https://doi.org/10.1007/s10826-017-1012-1

Fox, J., \& Holt, L. F. (2018). Fear of Isolation and Perceived Affordances: The Spiral of Silence on Social Networking Sites Regarding Police Discrimination. Mass Communication and Society, 21(5), 533-554. https://doi.org/10.1080/15205436.2018.1442480

Gelso, C. J. (2015). Counseling Psychology. In International Encyclopedia of the Social \& Behavioral Sciences: Second Edition. https://doi.org/10.1016/B978-0-08-0970868.21073-8

Handoko, P. (2021). The role of organisational experience to support job readiness: A phenomenological approach of fresh graduates. Technium Social Sciences Journal, 20(1), 668-679.

Hannan, A. (2021). CYBERSPACE DAN POPULISME ISLAM DI KALANGAN NETIZEN: STUDI KASUS PADA AKUN MEDIA SOSIAL FELIX SIAUW. Jurnal Sosiologi Reflektif, 15(2), 224. https://doi.org/10.14421/jsr.v15i2.2116

Hermawan, B., Salim, U., Rohman, F., \& Rahayu, M. (2019). Making Borobudur a Buddhist Religious Tourist Destination: An Effort to Preserve Buddhist Temples in Indonesia. International Review of Social Research. https://doi.org/10.2478/irsr-2019-0008

Ikasari, P. N. (2017). Perempuan dalam Diskriminasi Etnis Di Indonesia (Analisis Film Sapu Tangan Fang Yin ). Jurnal Komunikasi Dan Kajian Media, 1(1), 57-68.

Indrasari, M., Purnomo, B. R., Yunus, E., Syamsudin, N., \& Kartini, I. A. N. (2018). Phenomenological Study: Determinants of Success of Women Entrepreneurs in Surabaya. 165(Iccsr), 410-414. https://doi.org/10.2991/iccsr-18.2018.90 
Jatmiko, M. I. (2019). Hibridisasi Masyarakat Tionghoa di Kecamatan Lasem PascaReformasi. Umbara, 4(2), 101. https://doi.org/10.24198/umbara.v4i2.21697

Khalsa, G. S., Welle, R., Royse, E., \& Kopystynsky, N. (2020). Acculturation stress in Northern Colorado: A phenomenological study on the experiences and perspectives of refugee aid service providers. Translational Issues in Psychological Science, 6(3), 283-293. https://doi.org/10.1037/tps0000273

Kim, H., \& Sim, I. (2021). The Experience of Clinical Nurses after Korea's Enactment of Workplace Anti-Bullying Legislation: A Phenomenological Study. International Journal of Environmental Research and Public Health, 18(11), 5711. https://doi.org/10.3390/ijerph18115711

Koch, I., Poljac, E., Müller, H., \& Kiesel, A. (2018). Cognitive structure, flexibility, and plasticity in human multitasking-an integrative review of dual-task and taskswitching research. Psychological Bulletin, 144(6), 557-583. https://doi.org/10.1037/bul0000144

Lailawati, F. D. (2020). Penghapusan diskriminasi, ras, dan etnis pembuatan surat keterangan waris yang didasarkan pada penggolongan penduduk. Jurnal Cakrawala Hukum, 11(1), 12-20. https://doi.org/10.26905/idjch.v11i1.4051

Liang, Z., Cheng, L., Shao, S., Jin, X., Yu, T., Sleigh, J. W., \& Li, X. (2020). Information integration and mesoscopic cortical connectivity during propofol anesthesia. Anesthesiology, (Xxx), 504-524. https://doi.org/10.1097/ALN.0000000000003015

Littlejohn, S. W., \& Foss, K. A. (2008). Theories of Human Communication 9th Edition. California: Cengage Learning.

Livari, N. (2018). Using member checking in interpretive research practice: A hermeneutic analysis of informants ' interpretation of their organizational realities Netta Iivari This is the peer reviewed version of the following article : Netta Iivari , ( 2018 ) " Using mem. Emerald Insight, 31, 111-133.

Mafaza, M., Anggreiny, N., \& Alfara, H. (2018). Parenting Self Efficacy pada Orang Tua dengan Tuna Netra. Jurnal Ilmu Perilaku, 1(2), 110. https://doi.org/10.25077/jip.1.2.110-124.2017

Marta, R. F. (2018). Polemik Kebhinnekaan Indonesia Pada Informasi Instagram @Infia_Fact Terkait Patung Kwan Sing Tee Koen Tuban. Bricolage: Jurnal Magister Ilmu Komunikasi, 3(02), 63-71. https://doi.org/10.30813/bricolage.v3i02.922

Miller, W. L. (2020). Experiences of Stigma and Spirituality of Older Black Men Living with HIV. Journal of Social Service Research, 46(3), 427-438. https://doi.org/10.1080/01488376.2019.1582451

Mirawati. (2017). Kematangan Sosial Siswa Kelas XII Di SMK TI Swasta Budi Agung Ditinjau Dari Keyakinan Diri Akademik Dan Jenis Kelas. Jurnal Psikologi Kognisi, 2(1), 15-29. 
Pan, Z., Lu, Y., Wang, B., \& Chau, P. Y. K. (2017). Who Do You Think You Are? Common and Differential Effects of Social Self-Identity on Social Media Usage. Journal of Management Information $\quad$ Systems, 34(1), 71-101. https://doi.org/10.1080/07421222.2017.1296747

Prathama, N. A. (2019). Aktivitas Pemrosesan Informasi SARA Dari Media Sosial.Tesis Ilmu Komunikasi. Universitas Diponegoro Semarang.

Rochim, M., Bajari, A., Damayani, N. A., \& Bakti, I. (2020). Community-based disaster communication management. Jurnal Komunikasi: Malaysian Journal of Communication, 36(4), 339-350. https://doi.org/10.17576/JKMJC-2020-3604-21

Sholiha, S., \& Aulia, L. A.-A. (2020). Hubungan Self Concept dan Self Confidence. Jurnal Psikologi : Jurnal Ilmiah Fakultas Psikologi Universitas Yudharta Pasuruan, 7(1), 4155. https://doi.org/10.35891/jip.v7i1.1954

Solihah, R., \& Witianti, S. (2017). Permasalahan dan Upaya Mewujudkan Pemilu Demokratis di Indonesia Pasca Reformasi||. Jurnal Bawaslu.

Sternberg, R. J. (2018). Why real-world problems go unresolved and what we can do about it: Inferences from a limited-resource model of successful intelligence $†$. Journal of Intelligence, 6(3), 1-9. https://doi.org/10.3390/jintelligence6030044

Tinarbuko, S. (2019). Membaca Makna Iklan Politik Pilpres 2019. Mudra Jurnal Seni Budaya. https://doi.org/10.31091/mudra.v34i2.707

Wuri, D. M. (2017). Identitas Kosmopolitan Dan Parokial Pekerja Migran India Di Batam Sebagai Strategi Negosiasi Budaya. Paradigma, Jurnal Kajian Budaya, 5(1), 21. https://doi.org/10.17510/paradigma.v5i1.162

Xiong, A., \& Proctor, R. W. (2018). Information processing: The language and analytical tools for cognitive psychology in the information age. Frontiers in Psychology, 9(AUG). https://doi.org/10.3389/fpsyg.2018.01270

Yunitasari, N. P. A. G., Kanto, S., \& Chawa, A. F. (2018). The Interpretation of the OmedOmedan Tradition by the Community in Banjar Kaja , Traditional Village of Sesetan , Denpasar , Bali. Journal of Philosophy, Culture and Religion, 37, 18-22.

Yusriyah, K., Fatoni, A., \& Mansyur, M. A. (2020). Communication Networks Analysis on Information Dissemination of the Moving of Capital City From Jakarta to East Kalimantan. Aspiration Journal.

Zuccarini, M., Ledonne, G., \& Bonetti, L. (2017). Clinical training and perception of its effects on the first novice nurse work experience: a phenomenological study. Europe PMC, 195-205. https://doi.org/https://doi.org/10.7429/pi.2017.704195 